\title{
Income inequality and wealth concentration in the recent crisis
}

\author{
Thomas Goda ${ }^{\mathrm{a}}$, Özlem Onaran ${ }^{\mathrm{b}}$, and Engelbert Stockhammer ${ }^{\mathrm{c}}$
}

\begin{abstract}
This article shows that the increase of income inequality and global wealth concentration was an important driver for the financial and Eurozone crisis. The high levels of income inequality resulted in balance of payment imbalances and growing debt levels. Rising wealth concentration contributed to the crisis because the increasing asset demand from the rich played a key role in the growth of the structured credit market and enabled poor and middle-income households to accumulate increasing amounts of debt. This analysis is the first that puts both income and wealth inequality to the epicentre of the recent crisis, and is crucial for social scientists researching on not just the effects but also the causes of the crisis related to inequality. Our findings strongly suggest that the policy response to the crisis must not be limited to financial regulation but should involve policies to address inequality by increasing the bargaining power of labour as well as redistributive tax policies.
\end{abstract}

Keywords: Financial crisis, Eurozone crisis, distribution, income inequality, wealth concentration

JEL codes: D31, G01, E25

a Universidad EAFIT, School of Economics and Finance, Carrera 49 \# 7sur - 50, Medellin , Colombia; +57 42619500 - 8664; tgoda@eafit.edu.co (corresponding author).

b University of Greenwich, Department of International Business \& Economics, Old Royal Naval College, Park Row, London, SE10 9LS, UK; +44 208331 8519; o.onaran@gre.ac.uk.

c Kingston University, Department of Economics, Penrhyn Road, Kingston Upon Thames, KT1 2EE, UK; +44 208417 7774; e.stockhammer@kingston.ac.uk. 


\section{INTRODUCTION}

Economic inequality has become a prominent topic in public debate after the publication of Piketty's (2014) book Capital in the Twenty-First Century. The last time that the topic reached such a prominence was in the 1930s when it was widely accepted that inequality was a cause for the Great Depression (Eccles, 1951; Galbraith, 1975). As a response policy makers of developed countries increased top marginal income and wealth taxes sharply, regulated markets, and strengthened the social welfare system during the middle of the twentieth-century. The result of these policies, which went hand in hand with the post-war boom in OECD countries, was a sharp decline in inequality levels.

During the 1970s falling profits created growing discontent with the economic status quo by the ruling elite, which in turn contributed to a push towards neoliberal reforms so that most regions in the world deregulated markets, strengthened corporate control and lowered personal and corporate taxes, resulting in a deterioration in working conditions and labour's bargaining power and a polarization of income and wealth at levels not seen since the 1930s (Vidal, 2013; Crotty, 2012; Piketty, 2014).

Authors like Stiglitz (2012), van Treeck (2014) and Kumhof et al. (2015) argue that rising income inequality was a root cause for the rapid growth of the US non-prime mortgage market and the global balance of payment imbalances that contributed to the Great Recession. Moreover, Lysandrou (2011b), Milanovic (2011) and Goda and Lysandrou (2014) stress that the global rise in the absolute concentration of wealth was an important contributing factor to the financial crisis, because the growing demand from very rich individuals for investable securities was a major driver behind the growth of the structured credit market.

This article shows that the integration of these two strands of research, which analyse distinct transmission mechanisms of the contribution of inequality to the crisis, is important for a better understanding of the mechanisms behind the crisis. We therefore extend the existing literature on the complex relation between inequality and financial instability by integrating the analysis of income inequality and wealth concentration and its effects on consumption and debt levels, balance of payment imbalances, and financial innovation more thoroughly than in the previous literature. The article is also distinct in that it analyses the financial crisis in the US as well as the sovereign debt crisis in the Eurozone. The crisis in the Eurozone and the global financial crisis 
typically are analysed in isolation, but we argue that they are interconnected. To be more precise, we argue that the Eurozone crisis was triggered by the financial crisis, and that in the US as well as in the Eurozone high levels of inequality contributed to balance of payment imbalances and growing private debt levels.

We believe this analysis is crucial for social scientists with an interest in the social consequences of the crisis (see e.g. Sidaway, 2008; Fujita, 2010; Bassens et al., 2013; Munoz Martinez and Marois, 2014) in order to better understand how causes of the crisis are related to income and wealth inequality. The mainstream economic analysis of the crisis has been narrow and fails to incorporate socio-economic variables like inequality in their analysis (see Stiglitz, 2011 for an in-depth discussion). Instead, the mainstream focuses on the regulation of global financial markets (e.g., Davies, 2010; Major, 2012), central bank policy failures (e.g., Taylor, 2009), market failures (e.g., Ashcraft and Schuermann, 2008) and irrational behaviour (e.g., Akerlof and Shiller, 2009). Our study, on the contrary, puts inequality to the epicentre of the crisis and is an attempt to question neoliberal policies, which were the driving force behind the rise in inequality and still dominate policies under the heading of the so-called structural reforms since the crisis, despite their failure to generate growth (Vidal, 2013; Stockhammer, 2015). The results of this analysis strongly suggest that the policy response to the crisis must not be limited to financial regulation but needs to involve policies that increase the bargaining power of labour as well as redistributive wealth taxation.

The next section shows how the financial crisis began in the market for subprime derivatives and morphed into a financial crisis, an economic crisis and, in the Eurozone, in a sovereign debt crisis. The third section clarifies why income inequality was a main ingredient for the emergence of debt-driven and export-driven growth models, and an important reason behind the rise of current account imbalances. The fourth section illustrates how global wealth concentration contributed to these developments and argues that increasing wealth holdings at the top were a crucial driver behind the securitization of (subprime) loans. The overall findings of the article and policy recommendations are consolidated in section five.

\section{FROM THE US SUBPRIME CRISIS TO THE EUROZONE CRISIS}


In summer 2007 the market for certain structured financial securities completely broke down. The reason for this was that the super senior tranches of CDOs started to suffer losses because of rapidly rising delinquency and foreclosure rates on US subprime mortgages. The collapse of the entire CDO market, in turn, led to uncertainty and panic in the global banking sector because the exact extent of the balance sheet risk exposure of financial institutions was unclear (Acharya $e t$ al., 2011; Shin, 2012).

The subsequent breakdown in trust between large commercial banks (many of whom owned or sponsored investment vehicles that were directly exposed to this market segment) set in motion a liquidity-solvency crisis spiral, which in September 2008 culminated in the paralysis of the whole financial system when the world's third largest investment bank, Lehman Brothers, declared bankruptcy and the insurance company American International Group (AIG) collapsed. The following flight to safe securities caused a decline in the government bond yields, most notably in the US, UK and Germany, and interbank lending literally stopped. The freezing of the interbank market meant that banks started to hoard liquidity, with the result that most households and firms lost access to credit.

The result was a global recession in 2008/09 and, subsequently, the Eurozone crisis that started in 2010. One outcome of the financial crisis and the recession was that European governments needed to rescue two types of banks: (i) banks that bought the toxic securities that triggered the subprime crisis, and (ii) highly leveraged banks that had a maturity mismatch and could not roll-over their debt. Another outcome was that government revenues declined while welfare spending increased. Accordingly, public deficits and public debt grew sharply in nearly all Eurozone countries. During 2008 and 2009 long-term government bond yields of these countries declined or stayed roughly stable due to the flight to safety by investors. However, in 2010 this situation started to change because investors became concerned about a possible default, leading to a rise in the refinancing costs for all countries. This increase in yields was relatively minor and temporary in those countries that had export-surpluses, whereas the periphery countries Greece, Ireland, Portugal, and to a lesser extent Spain (GIPS) experienced a longer lasting increase in risk premia.

The GIPS have in common that they experienced the build-up of a real estate bubble, rapidly increasing private debt, and significant current account deficits (ranging from $-2.1 \%$ in the case 
of Ireland ${ }^{1}$ to $-9.2 \%$ in the case of Portugal), which were financed by capital inflows from the rest of the world. An outcome of the 2007 crisis was that their real estate bubbles burst, which meant that some of their banks went into trouble and unemployment rates rose sharply along with a deep recession. The resulting increase in government expenditure and decrease in government revenue, coupled with their current account deficits, low growth perspectives, and relatively weak institutions, meant that investors increasingly feared that these countries would not be able to collect sufficient funds to repay their rapidly accumulating debt. This fear manifested in increasing sovereign risk premia. ${ }^{2}$ The hike in interest rates made a bailout program necessary as the refinancing costs for GIPS became too high. The accompanying austerity measures that were required from the European Commission, the European Central Bank and the IMF were detrimental. They resulted in a decrease in domestic demand that contributed to a sharp increase in unemployment, social unrest, a long economic depression, and a further rise in debt to GDP ratios.

This experience stands in stark contrast to that of current account surplus countries in the Eurozone (Germany Austria, Belgium, Finland and Netherlands). These countries not only produced more competitive export goods but their institutions also were perceived as being more effective $^{3}$, so that investors were confident that they would have no problem to raise the revenues necessary to repay their debt. Consequently, the demand for their bonds increased again in 2011, driving down their sovereign debt costs to historically low levels. Most countries engaged in a policy of modest fiscal stimulus during the recession 2008/09. But, while southern European countries shifted to sharp austerity after 2010, the fiscal policy stance in northern countries was rather neutral. This group of countries thus experienced a quick if shallow recovery from the

\footnotetext{
${ }^{1}$ Ireland is different from the other GIPS countries in that the source of its current account deficits were repatriated profits by multinational corporations and it had trade surpluses, although these deteriorated in the 2000s.

${ }^{2}$ An important reason for the sharp increase in the yields of Greek government bonds was that prior to the crisis the Greek administration misreported budgetary data, which came out when the new government presented a deficit that was more than twice as high as expected (Hoque, 2013). Portugal also had persistent deficits prior to the cris is, while Ireland and Spain had budget surpluses and very low public debt to GDP ratios in 2007 (25\% and 36\% respectively) that only increased sharply because of the recession and the high costs of their banking bailouts (especially in Ireland).

${ }^{3}$ According to World Bank's Worldwide Governance Indicators (WGI) the Eurozone export surplus countries on average had a perceived government effectiveness score of 1.8 points in 2010, whereas the GIPS countries had an average score of 1.0. The GIPS country with the highest score was Ireland (1.3), while Finland was the country with the best score among the export surplus countries (2.2). The indicator reflects the views of firms, citizens and experts and has a maximum value of 2.5 .
} 
2009 recession, although initially they were hit hard by the recession as a result of the sharp decline of their exports. This recovery was only short lived however, with the result that in 2013 the growth of both the current account surplus and the GIPS countries was either stagnating or negative.

This analysis shows that the main cause for the Eurozone crisis was not the lack of fiscal discipline in the periphery, as argued by many mainstream analysts (e.g. Schuknecht et al., 2011; Costa and Ricciuti, 2013), but rather the outcome of the loss in market confidence and the recession triggered by the financial crisis in combination with the current account imbalances within the region and the structural flaws of the European economic policy regime. It was the design of the European Monetary Union (EMU) that led to an escalation of the Eurozone crisis. The EMU has supported transnational capital flows rather than leaning against financial bubbles and it has imposed fiscal austerity in countries in recession. Most importantly the ECB has been mainly concerned with inflation targeting and reluctant to act as a lender of last resort for member states (Arestis and Sawyer, 2011; Stockhammer, 2011, 2016b; Sawyer, 2013; Storm and Naastepad, 2015c). Effectively, ECB support for national financial systems has been conditional on specific fiscal policy measures. In the standoff with Greece in spring 2015 the ECB has, by withdrawing liquidity support, effectively shut down a member state's financial system in order to enforce a certain fiscal policy stance. The goal of financial stability was subordinated to a political agenda. The initial trigger of the Eurozone crisis thus was the banking crisis, the following recession and the loss of confidence, while the causes of the crisis lie in the domestic property bubbles and the imbalances that had built up prior to the crisis. The reason why the crisis deepened and turned into a sovereign debt crisis are to be found in the EMU's policy regime however.

A distinctive feature of the pre-crisis era was an increase in income inequality within developed countries as well as a global increase in absolute wealth concentration (Piketty, 2014; Goda, 2014). While it is widely acknowledged that distributional issues have to figure somewhere in the plot of these events, the question arises if income inequality and wealth concentration was at the very root of the recent crisis. The remainder of this article intends to answer this question. 


\section{INCOME INEQUALITY AND DEBT- AND EXPORT-DRIVEN GROWTH}

Since the 1980s, there has been a clear reversal of the trends towards relatively egalitarian income distribution during the post-war era. On the one hand, there has been a significant decline in the share of wages in GDP across the globe (OECD 2012; Stockhammer, 2015, 2016b; Onaran and Galanis, 2014). Figure 1 shows the adjusted wage share in national income in the developed world. ${ }^{4}$ The share of wages has fallen by $10 \%$-points in the Eurozone, and even more in Japan. In parallel to this, in English speaking countries a sharp polarization of personal income distribution and a rise in the remuneration of top managers has occurred since the 1980s (Atkinson et al., 2011).

\section{[Figure 1]}

As can be seen in Figure 2, the share of the top 1\% of the income distribution in the US has reached $18 \%$ of GDP prior to the crisis, exceeding the levels before World War I and the Great Depression; the UK followed a similar pattern. Since managerial wages are part of wages, this has led to a more modest decline in the wage share in the US and the UK compared to continental Europe. Top income shares did not experience the same surge in continental Europe. In the case of Germany this can be explained partly by the fact that many companies retained large parts of their rising profits (Behringer et al., 2014). Nevertheless, similar to the US and the UK in Germany also a significant low wage segment emerged (Vidal, 2013). Nevertheless, whether the rise in personal income inequality was caused by a rise in top incomes or the generation of a low wage sector, in all the countries a trend towards greater inequality in personal income distribution went along with a fall in the wage share. ${ }^{5}$

[Figure 2]

\footnotetext{
${ }^{4}$ Wages are adjusted labour compensation (real compensation per employee multiplied by total employment).

${ }^{5}$ These developments are in line with a global trend of rising income inequality within countries, "about 80 per cent of the world's population now lives in regions whose median country has a Gini close to 40" (Palma, 2011, p.87).
} 
A fall in the wage share reflects falling unit labour costs, and increasing profitability. Mainstream economic policy, informed by neoclassical economics, thus expects the decline in the wage share to be associated with stronger growth and employment. However, since 1980 growth has not been particular strong in developed countries, which is a puzzle for mainstream economics. Post-Keynesian/Post-Kaleckian models ${ }^{6}$ suggest that wages have not only a role as cost item but also as a source of demand. To be more precise, a rise in inequality in the form of a fall in the share of wages will, other things equal, suppress domestic consumption since the marginal propensity to consume out of wages is higher than that out of profits. However, it may also have a positive effect on investment due to increased profitability, and improved international competitiveness might lead to higher net exports due to lower unit labour costs. In order to assess the effects of wage moderation it is necessary to address the effects on all three components of private demand. If the differentials in marginal propensity to consume between wages and profits is relatively large, but the responsiveness of investment to profitability and net exports to relative price changes are low, then the total effect of the increase in the profit share on aggregate demand and hence growth would be negative, and the demand regime is called wage-led. If the effect is positive, it is called profit-led. The question whether the negative effect of lower wages on consumption or the positive effect on investment and net exports is larger is an empirical issue.

Empirical research that have tried to identify these opposite effects (e.g. Naastepad and Storm, 2006-07, Hein and Vogel, 2008; Stockhammer et al., 2009; Onaran and Galanis, 2014) suggest three important findings: Firstly, consumption reacts more sensitively to a decrease in the wage share than does investment, hence domestic demand (consumption and investment) is wage-led in all countries. The character of the demand and growth regimes thus depends crucially on the relevance of the net export effects. Secondly, the effects via the international trade channel depend on the elasticity of exports and imports to prices and labour costs as well as the degree of trade openness. Relatively closed large economies (like the US and Germany) tend to be wage-led as opposed to relatively small open economies, where net exports may play a

\footnotetext{
${ }^{6}$ Post-Keynesian economics builds on Keynesian theory of effective demand. It deviates from mainstream Keynesianism in that it regards Keynes' work as break with the neoclassical traditions. In particular Post-Keynesians rejects the need for micro foundations and the marginal productivity theory of income distribution. It often uses class analysis as a foundation of macroeconomic analysis. See Bhaduri and Marglin (1990) and Lavoie (2009).
} 
major role in determining the overall outcome. Thirdly, in a large region like the Eurozone or in the current state of high international integration in the world economy the international competitiveness effects of declining wage shares are eliminated when the fall in the wage share takes place simultaneously across all countries.

The expected outcome of the race to the bottom in the wage share in Europe and in the global economy since the 1980 s should, therefore, have been a stagnation of global demand and growth. So how did the world economy or individual countries manage to grow prior to the Great Recession? Stagnation in demand was circumvented by two distinct growth models: (i) a debtdriven growth model in the US, UK, Australia in the core, and in the periphery in the GIPS and Eastern Europe; and (ii) an export-driven growth model in Germany, Austria, and Japan in the core. The debt-driven and the export-driven growth models are complementary in that the export-driven growth regimes can pursue mercantilist models only in the presence of debt-driven deficit countries. Hence both rely on increasing accumulation of debt, and they are both equally fragile reflecting the global imbalances that have grown dramatically in the 2000s; the unsustainability of these global imbalances became evident in the aftermath of the Great Recession.

At the root of both models lie different ways to react to the same chronic domestic demand deficiency due to declining wage shares. The way different countries dealt with this potential crisis of demand depended on their structural parameters regarding their position in the global value chains, history of industrial policies, employment relations, and differences in financialisation. Financial deregulation of the 1980s and the role of the financial industry were strongest in the US and the UK. In the periphery of Europe, European integration and the liberalization of capital flows was determinant in making debt-driven growth feasible.

International financial deregulation made persistent long-term current account imbalances in the debt-driven growth regimes feasible without major currency adjustments, which were in return financed by capital inflows from the export-driven countries with persistent current account surpluses. In 2007 Germany had a current account surplus of $7.5 \%$ of GDP, while the US had a deficit of $5.1 \%$. Exchange rates were not adjusting to trade imbalances but were determined by capital flows chasing financial return. International financial liberalization has thus created the conditions for debt-driven and export-driven growth models to co-exist for 
extended periods as long as the financial investors find the debt situation in the debt-driven growth models sustainable.

As discussed in Section 2, within the Eurozone itself, the crisis laid bare former divergences caused by the process of monetary union. Productivity and production structures did not converge, and although inflation rates came down in all countries, the countries that had low inflation prior to the Euro also had lower inflation afterwards, which led to the increasing divergence of nominal unit labour costs (Stockhammer and Onaran, 2012). In conjunction with differences in technological competitiveness and an economic boom built on rising property prices and household debt this resulted in sizable current account disequilibria across the Eurozone. ${ }^{7}$ Accordingly, the Southern and Eastern periphery of Europe has experienced massive capital inflows for more than a decade from the trade surplus countries (most of all Germany), which led to the accumulation of massive external liabilities in the trade deficit countries that has financed debt-driven spending.

In Greece it was mostly the government sector that accumulated debt, in Ireland, Portugal, and Spain it was rather the private sector, and in particular the household sector (Lapavitsas et al., 2010): between 2000 and 2008 private household debt to GDP ratios increased by 62, 21 and $33 \%$-points in Ireland, Portugal and Spain respectively, whereas it shrank in Germany by $11 \%$ points (Stockhammer, 2016a, 2015) In the debt-driven countries, growth driven by increasing debt, financed by capital inflows led to asset and/or property price bubbles, which fuelled the increase in debt via equity withdrawals. In the export-driven countries, on the contrary, net exports have provided the main driving force for demand. In the extreme case of Germany, three quarters of GDP growth has been driven by net exports since 2000 (Stockhammer and Onaran, 2012).

How far does our argument differ from the existing literature? To begin with, most mainstream economics regards the crisis foremost as a financial issue (e.g. Blanchard, 2009; Brunnermeier, 2009; Roubini and Mihm, 2010), while distributional considerations are often disregarded. There are some exceptions though. Rajan (2010) contends that skill-biased technological change increased permanent inequality in the US, and, induced the US government

7 Storm and Naastepad (2015a; 2015b) argue that the debt-based spending boom and the low technological competitiveness of peripheral Eurozone countries were more important to explain these disequilibria than unit labour cost differences. 
to encourage credit growth in general and the subprime mortgage market in specific to expand consumption. Stiglitz $(2009 ; 2012)$ also argues that aggregate demand would have been insufficient without a rise in private debt levels that "fuelled a consumption boom that allowed Americans to live beyond their means" (Stiglitz, 2012:54). In contrast to Rajan, for Stiglitz the main reasons for this situation were that poor and middle-income households tried to keep up with the richer parts of the society, and that rent seeking led to market distortions.

Kumhof and Ranciere (2010) and Kumhof et al. (2015) develop a dynamic stochastic general equilibrium (DSGE) model with investors and workers, in which an increase in inequality results in rising debt of workers that is financed from savings from investors. As workers become overindebted, the number of defaults increases, and a financial crisis emerges. A shortcoming of this model is that it does not involve asset and property price bubbles and that lending is solely driven by savings. In none of these mainstream contributions are the emergence of different growth regimes and the role of inequality in contributing to balance of payment imbalances central. The only exception is Kumhof et al. (2012), who extend the Kumhof and Ranciere (2010) model to a two country case where the rich population in countries with less developed financial markets finances the rising debt of the poor population in countries with more developed financial markets. However, they do not analyse the imbalances within the Eurozone, and, specifically, they do not explain why countries with highly developed financial markets (like Germany) also have financed the poor population in other countries.

The same is true for Fitoussi and Saraceno (2010), who argue that rising income inequality depressed aggregate demand in both the US and in Europe. However, the increase in inequality was accompanied by above potential growth rates in the US and UK as opposed to sluggish growth rates in most continental European countries. These growth differences are explained by the fact that financial deregulation increased the ability of US, UK, and Spanish households to indebt themselves, while this was not so easily possible for German, French and Italian households. Moreover, the authors state that the relatively unsuccessful German export-driven growth strategy (in terms of growth) can be explained by the more expansionary fiscal policy in the US.

Among Post-Keynesian and Marxian economists the issue of income distribution has featured more prominently. Two notable Post-Keynesian analyses are Palma (2009) and 
Galbraith (2012). Palma discusses in detail the pre-crisis income polarisation in the US, and he argues that a crucial reason behind the crisis was that neoliberalism reduced the pressure for large companies to engage in competitive struggles in the real economy so that rent-seeking intensified which, in turn, destabilized the system. Galbraith's contribution mainly focusses on pay disparities across industries and regions, and their contribution to global income inequality trends during the last thirty years. Moreover, he argues that finance is an important factor to explain these disparities and he claims, in line with Rajan (2010), that "the Bush administration launched the 'ownership society', overtly encouraging massive expansion of lending to weak credits, and relaxing the regulatory standards that had previously protected credit quality in this area. Before too long, the subprime boom was under way" (p.293).

Several other heterodox authors - like Foster and Magdoff (2009), Hein (2012), Palley (2012), Cynamon and Fazzari (2013), and van Treeck (2014) - have offered analyses that substantially overlap with ours. They show that prior to the crisis a structural demand gap in the US, due to the fact that wages were increasing more slowly than productivity, was hidden by the growth of the financial sector and increasing household debt of the bottom $95 \% .{ }^{8}$ While this debt-driven consumption allowed the US to grow prior to the crisis, the demand impact turned negative after the crisis when the bottom 95\% households could no longer finance their consumption with debt. ${ }^{9}$ As a result growth rates are now well below their pre-crisis trends in the US (Palley, 2015; Cynamon and Fazzari, forthcoming). ${ }^{10}$ Foster and Magdoff (2009), Palley (2012) and van Treeck (2014) also stress that the debt-driven growth model led to a large current account deficit in the US, and Behringer and van Treeck (2013) argue that rising top income shares had similar effects in countries like the UK and Italy. The work of Hein (2012) and Hein and Mundt (2012) are closest to ours. Both identify rising inequality, rising household debt,

\footnotetext{
${ }^{8}$ Barba and Pivetti (2009, Hein (2012) and van Treeck (2014) argue that US households increased their debt to keep up their consumption with richer parts of the population (the so called 'keeping up with the Joneses' effect)

${ }^{9}$ One reason why this debt-driven growth was no longer possible was a sharp decrease in the wealth of poor and middle income households. Wolff (2012) shows that between 2007 and 2010 median household wealth in the US nearly halved.

${ }^{10}$ A study by Cripps et al. (2011), using a stock-flow consistent (SFC) model, furthermore suggest that under the current conditions the pattern of underconsumption in some countries and over-borrowing in other countries will prevail, with the outcome that it is likely that global imbalances and crises will reemerge.
} 
global imbalances, and financial deregulation as the main causes of the crisis; and they distinguish between debt-driven and export-driven regimes.

In contrast to this analysis, most of the Marxist literature concentrates on overproduction- $\mathrm{a}$ surplus of capital and lack of investment opportunities - , rarely distinguishes between different growth regimes and mainly focuses on US developments. Exceptions are Brenner (2009), Dumenil and Levy (2011), Lim and Khor (2011) and Vidal (2013) who discuss international imbalances and acknowledge debt-driven growth. A common shortcoming of this research is that imbalances within the Eurozone are not discussed in relation to inequality ${ }^{11}$. Moreover, these studies mainly concentrate on demand formation in the real sector but do not analyse the impact of wealth distribution and demand formation in the financial market in depth, to which we turn in the next section.

\section{GLOBAL WEALTH CONCENTRATION AND ASSET MARKETS}

Prior to the current crisis, not only functional and personal income inequality but also the extent of wealth accumulation at the top increased dramatically. Wealth concentration can be measured in relative and absolute terms. Relative wealth concentration refers to the possession of disproportionate shares of wealth at the top. It is well documented that relative wealth concentration is normally higher than relative income concentration, and that the trend changes in top wealth shares (Figure 3) have been to some extent similar to that of top income shares (Figure 2). After World War I the extreme top wealth shares in Europe and the US decreased significantly, while they started to increase again from the late 1970s onwards. There exists very little data for countries from other regions but estimates suggest that within inequality has increased in most countries during the 2000s and that the global top $1 \%$ share currently is around $46 \%$ of total global wealth (Goda, 2014).

\section{[Figure 3]}

\footnotetext{
${ }^{11}$ Lapavitsas et al. (2010) emphasizes the structural contradictions of the Euro as a single currency to explain the imbalances; their focus is not on inequality as a root cause of the sovereign debt crisis.
} 
In order to analyse the effect of wealth concentration on financial investment demand, it is important to consider changes in the absolute amount of global wealth holdings on the top of the wealth distribution. The amount of absolute wealth holdings is important insofar as they determine how much financial investment demand the wealthy people have, and the global pool rather than wealth in a single country in isolation is the relevant indicator as financial capital is highly mobile. Unfortunately, "official publications do not report estimates of absolute inequality" (Atkinson and Brandolini, 2010:3). However, some private wealth reports provide estimates of the amount of global wealth holdings of those individuals who have a net worth of at least US\$1 million (primary residency excluded) - so called high net worth individuals (HNWIs).

According to these reports, between 1986 and 2012 HNWIs' wealth increased 6.6-fold from US\$ 7.2 trillion to US\$ 46.2 trillion - and billionaires' wealth even more than 15 -fold. ${ }^{12}$ The increase in absolute wealth concentration was especially steep in the years prior to the crisis. HNWIs' net wealth increased more than 1.5-fold between 2002 and 2007, from US\$26.7 to US\$41 trillion, while the global wealth holdings of billionaires increased 2.3-fold to US\$3.5 trillion. This growth can be explained partly by the growth of the HNWI population (from 7.3 million to 10.1 million individuals) and partly by the increase of the mean wealth per HNWI (from US\$3.66 million to US\$4.03 million). The tremendous growth in wealth holdings at the top means that Rockefeller today would not be within the top 20 of the global billionaires list and that at the end of 2012 the four wealthiest men -Slim, Gates, Ortega, and Buffet- were more than twice as rich as Rockefeller was in 1937 (Goda, 2014).

One reason for this increase of absolute wealth holdings of HNWIs was an increase in top incomes (Saez and Zucman, 2014). Personal income inequality and wealth concentration tend to be self-reinforcing because high income households save a higher proportion of their income and "wealth has a substantial impact on the share of income earned by those in the top 0.5 percent of the [adjusted gross income] distribution" (Tuttle and Gauger, 2006:506). Another reason for this exceptional increase in wealth concentration was the sharp increase of global stock market prices and real estate values, since increasing as set prices automatically translate into higher wealth

\footnotetext{
${ }^{12}$ During the same period global GDP only increased 4.8-fold in current terms.
} 
holdings of their owners, who mainly belong to the richest segment of the population (Wolff, $2010 ; 2015) .^{13}$

In contrast to income inequality, few studies discuss possible economic effects of the increase in absolute wealth accumulation at the top. Froud et al. (2001) argue that household savings from the richer parts of the US and UK society are increasingly invested in existing financial securities rather than the real sector. The result is that companies cannot generate enough returns to satisfy investors' profit expectations. This 'symptom of low returns' forces companies (i) to divert their activities into areas with higher returns, and (ii) to boost their share prices, both of which lead to a 'coupon type of capitalism' in which the financial sector becomes more and more important and stock market bubbles are building-up. Similarly, Wisman and Baker (2012) and Wisman (2013:922) claim that by "seeking profitable outlets for its dramatically increased income and wealth, the elite fuelled first a stock market boom and then, after the high-tech bubble burst, a real-estate boom" in the US.

Indeed, between 1997 and 2007 increasing global wealth holdings went hand in hand with a sharp increase in stock market and housing prices in the US and the Eurozone. The fact that global wealth holdings were increasing continuously and to a stronger degree than the asset prices in the US and Eurozone is consistent with the view that the former were driven the latter. (Figure 4). The resulting price rally in stock and real estate markets, in turn, contributed to the existence of the above discussed debt-driven growth regime in the US, the UK and GIPS countries as they provided greater collateral to low- and middle-income households, which enabled them to accumulate increasing debt.

\section{[Figure 4]}

Political economists also have acknowledged that the toxic securities that triggered the crisis were partly created because 'there is a growing 'wall of money' facing global financial markets that is looking for investment opportunities" (Engelen et al., 2010:47), which means that the

\footnotetext{
${ }^{13}$ In the US, "between 1983 and 2010, the top one percent received 38 percent of the total growth in net worth, 41 percent of the total growth in non-home wealth, and 39 percent of the total increase in income. The figures for the top 20 percent are 101 percent, 100 percent, and 104 percent, respectively-that is to say, the upper quintile got it all!" (Wolff, 2012, p.44).
} 
crisis "is also a story of the financialization of consumer credit networks [that enabled] lenders of all kinds to generate new assets" (Langley, 2008, pp. 136-137). However, in the se discussions wealth concentration normally is not mentioned but instead emphasis is laid on rising asset demand from institutional investors, governments and sovereign wealth funds. This is a shortcoming, given that the asset demand from the rich was higher than that of institutional investors. In 2007 HNWIs had more asset under management (US\$41 trillion) than global pension funds (US\$28 trillion), mutual funds (US\$26 trillion) and insurance companies (US\$20 trillion) (IFSL, 2008).

Milanovic (2011), Wisman (2013) and Foster and Magdoff (2009) partially address this shortcoming, although in a different manner. Milanovic states that "[h]igh-net-worth individuals and the financial sector were ... keen to find new lending opportunities" (p.195) to overcome a shortage of investment opportunities. Wisman (2013, p.940) argues that "investment funds were being switched from production to speculation, which stimulated innovations in credit instruments". Foster and Magdoff (2009, p.61) affirm that "the redistribution of wealth upward (through reduced taxes and reductions in social services) - the results of class war waged unilaterally from above-have not been enough to guarantee an ever-increasing spiral of return on capital invested in the productive economy. Thus, continual recourse to new forms of gambling, not production of goods or services, is what capital is generating in the pursuit of profit". However, these authors do not provide concrete evidence for these claims nor do they specify a concrete transmission mechanism between wealth accumulation and the production of structured securities.

Lysandrou (2011a; 2011b) is the first author to present data and theorize the link between the increase in absolute wealth concentration and CDO production in more detail. His innovative argument is that the increasing net wealth from HNWIs led to an increasing demand for financial products (rather than material goods). This demand, in turn, motivated banks to engage in financial innovation to overcome a global shortage of investable securities. To alleviate this shortage the market for asset backed securities (ABS) and CDOs was rapidly expanded. A shortcoming of Lysandrou's work is that he does not provide strong empirical evidence for his claim (especially regarding causation). To give credibility to this theory it needs to be shown that (i) one driving force behind the mortgage securitization growth was a fall in the yield of 
traditional debt securities, (ii) HNWIs contributed to this fall, and (iii) these individuals also created a demand pressure for CDOs.

Evidence regarding the first point has been provided by Caballero et al. (2009), Bernanke (2011), and Goda et al. (2013). Especially after 2000 many emerging market economies (EMEs) were experiencing high growth rates, but their debt security market could not keep up with this development. EMEs' bond markets stayed "underdeveloped"; at the end of 2007 the EMEs' share in global GDP was one-third whereas their share in world debt security markets was only ten percent (IMF, 2008). Due to this global mismatch investors were increasingly "forced" to invest in the US where most financial assets are produced (Caballero and Krishnamurthy, 2008). The resulting capital inflows not only helped to finance the debt-driven growth model of the US, but also led to the phenomena that the supply of traditional investment grade debt securities could not keep up with the growing global demand for these securities. Government purchases from export surplus countries like China lowered long term yields of US Treasury and agency bonds, while foreign and domestic private investor demand reduced US agency, corporate, and municipal bonds yields (Bernanke, 2011; Bertaut et al., 2012; Goda et al., 2013). ${ }^{14}$ The depressed yields, in turn, led to a search for alternative debt securities with a higher yield. An excess safe asset demand on the part of investors was thus a chief force that drove the expansion of the US CDO market (Goda et al., 2013).

But, in how far were HNWIs from the US and the rest of the world involved in this global excess demand? To answer this question, Goda and Lysandrou (2014) estimate the size of HNWIs' US bonds holdings and their involvement in the demand pressure, and find that more than half of HNWIs wealth is comprised of financial securities of which around half is comprised of debt securities. Moreover, HNWIs bond holdings are heavily skewed towards the US market which is by far the biggest and most liquid market in the world. The rise in HNWIs wealth holdings thus meant that HNWIs from the US and the rest of the world increased their total holdings of US bonds by around forty percent between mid-2004 (US\$2.1 trillion) and mid-

\footnotetext{
${ }^{14}$ Bernanke $(2005,2011)$ and Bertaut et al. (2012) argue that the US bond demand was mainly driven by 'excess' savings in emerging markets, but also by changing portfolio preferences in European countries. We have two issues with this argument. First, theoretically it is based on a loanable funds interpretation of financial markets where savings are invested. This contrasts with a Keynesian view, where finance and credit (rather than saving) are the key for explaining capital flows (e.g. Borio and Disyatat 2011). Second, Goda et al. (2013) show that the demand from private US investors also increased substantially and partly explain the depressed yields of AAA-rated agency, municipal, and corporate bonds.
} 
2007 (US\$2.9 trillion). ${ }^{15}$ The rise in HNWIs bond holdings meant that very rich individuals significantly depressed long-term bond yields in the US (Goda and Lysandrou, 2014). This result suggests that HNWIs significantly contributed to the above mentioned shortage of traditional debt securities, which triggered a "search for yield" by all global investors that helped to encourage the demand for CDOs. ${ }^{16}$

As regards the third point it has to be shown that HNWIs also were involved in the demand pressure for CDOs. Rich investors were not directly involved in this market, but indirectly via hedge funds, who held nearly half of all issued CDOs by June 2007 (Blundell-Wignall, 2007). The absence of rich individuals' direct involvement most likely can be explained by the complex nature of $\mathrm{CDOs}^{17}$, whereas the dominant position of hedge funds can be mainly explained by two factors: (i) the exceptional growth of this industry ${ }^{18}$, and (ii) the pressure that they faced to generate above average yields by the investors whose funds were managed by the hedge funds. An important driver behind this growth and pressure was the increasing investment of HNWIs, who increased their hedge fund assets approximately from US $\$ 500$ billion to US $\$ 1,1$ trillion between 2002 and 2007 (Goda and Lysandrou, 2014).

Hedge fund managers were content with their growing asset base, but it also provided them with a problem. To maximize returns hedge funds rely on leverage, and to get access to cheap credits they need to provide investment grade collateral to banks. Given that investment grade

${ }^{15}$ Goda and Lysandrou (2014) estimate that around $60 \%$ of US individual bond holdings were held by US HNWIs prior to the crisis, while $20 \%$ to $30 \%$ of foreign private bond holdings stemmed from rest of the world HNWIs. Different estimates by Hager (2014) confirm that US bond holdings are concentrated in the hands of the top $1 \%$ of the population.

${ }^{16}$ Around $70 \%$ of all CDO tranches were investment grade, but although they had the same rating as investment grade bonds their structure allowed them to provide better returns than these securities. The underlying assets of CDOS were mainly low-rated ABS tranches (and non-investment grade loans and bonds), which provided relatively high cash-flows. The reason why most CDO tranches received investment grade, despite the bad rating of their collateral, was the bundling of different assets from different originators and the (wrong) assumption that debtors have independent default probabilities-see Blundell-Wignall (2007) and Coval et al. (2009) for more details.

${ }^{17}$ An owner of ordinary debt securities can easily find out how risky the investment is and in how far the risk of default changes over time. The same is true for ABS investors as the backing collateral also consists of a single, homogenous class of assets. CDOs, by contrast, do not meet this transparency criterion as they are backed by many different types of asset classes (in their simplest form a CDO is an ABS of many ABS). That is why each CDO's price is negotiated over the counter by the seller and the buyer, i.e. CDOs have no standard prices.

${ }^{18}$ Hedge funds' assets under management more than tripled during 2002-2007, reaching US\$2.2 trillion in 2007. 
bonds had historical low yields, hedge funds needed to find an alternative that was accepted by banks and at the same time kept borrowing costs to a minimum. CDOs were the solution to this problem. Their senior tranches could be used as collateral that gave a decent return, while their equity tranches were seen as high yielding investment opportunity whose risk could be controlled by using put options and credit default swaps ${ }^{19}$. This strategy allowed hedge funds to generate an above average return for their clients and high bonus payments for themselves, and at the same time generated demand for banks to supply increasing amounts of CDOs. This analysis suggests that the historical high level of absolute wealth concentration is crucial to explain why the CDO market reached a size that was sufficiently large to endanger the global financial system when it collapsed in August 2007. Our analysis of the effects of wealth concentration on financial markets has focussed on the USA. This reflects the state of available research. As of yet there are no studies that would investigate the impact of HNWI wealth holdings on real estate prices and sovereign debt yields for European countries. This would be an important area for future research.

\section{CONCLUSIONS}

Our analysis demonstrates that it is crucial to take both income and wealth inequality equally into account to grasp the complex relationship between inequality and financial stability, and to show that the financial crisis and the Eurozone crisis are interconnected. Figure 5 summarizes our argument.

\section{[Figure 5]}

Rising income inequality has led to potentially stagnant demand, because the world economy overall is in a wage-led demand regime. In Neoliberalism this has been overcome via either debtdriven or export-driven growth models. The debt-driven growth model relied on asset and property bubbles to generate credit that ultimately fuelled consumption. This allowed working class households in OECD countries to maintain growing consumption while their incomes

\footnotetext{
${ }^{19}$ Put options enabled hedge funds to sell an equity tranche at a specified date at a specified price. Credit default swaps gave hedge funds the right to be compensated in the case of default.
} 
stagnated (in particular in the US and the UK). These countries usually had large current account deficits and effectively played the role of a growth engine of the world economy. The exportdriven growth model had stagnant domestic demand and used net export growth as the source of demand growth. Both growth models are intrinsically unstable, since they both rely on increasing debt to income ratios. In the debt-driven model household debt has risen to allow for growth. However, the export-driven growth model also relies on rising debt, but it is not domestic debt, but rising foreign debt of its trade partners. The debt-driven and export-driven growth models are thus complementary and they have resulted in rising household debt, international imbalances and rising international debt.

Global wealth concentration played an important role in providing the finance for these unstable growth regimes. Rich households (or their trusts) save differently from working class households: they save a higher share of their income and hold riskier assets. The superrich, or more technically, HNWIs, played a crucial role in that (i) their increasing as set demand helped to lower the yield of traditional bond classes, which put pressure on investors to seek alternative investment grade fixed income securities that provided higher yields, and (ii) HNWIs were the main investors in hedge funds, which, in turn, were the main buyers of CDOs. HNWIs thus helped to create the institutions that aggressively developed new financial instruments and, ultimately, they provided the funding for subprime loans and growing credit more broadly. Economic inequality thus played a crucial role on both the supply and demand sides of the market of the toxic securities that were at the epicentre of the financial crisis. While this has been documented for the USA, the literature has yet to establish how the growing asset demand of HNWIs has affected to the stock market and housing prices in the Eurozone and to what extent they enabled low- and middle-income households in debt-driven Eurozone countries to accumulate debt. The banking crisis, recession and the loss of confidence that followed the subprime crisis laid bare the unsustainability of this growth model and showed that economic inequality was a crucial contributing factor not only for the crisis.

Many elements of our argument can be found in the literature. In particular the link between income inequality and rising household debt has become widely accepted among many PostKeynesians and, to a lesser extent, by Marxians and is also discussed at the critical fringes of the mainstream (as discussed in Section 3). The emergence of debt-driven versus export-driven growth regimes and the impact of wealth concentration on financial (in)stability are much less 
widely recognized though. Importantly, most of the literature focuses on the US. Our approach differs in several ways. Firstly, our internationally comparative analysis exposes that countries have relied on debt- or export-driven growth models in reaction to the rise in inequality. Secondly, we systematically highlight the link between inequality and demand formation in the real and the financial sector and thereby integrate the analysis of income inequality and wealth concentration and its effects on consumption and debt levels, balance of payment imbalances, and financial innovation. Finally, our paper also discusses the link between debt- and exportdriven growth regimes, wealth concentration, and the Eurozone crisis.

These findings suggest various avenues for future research. First, the interaction between different growth regimes needs further analysis. In particular the contribution of capital inflows to asset and property price bubbles in advanced economies is under-researched. Second, the effect of inequality on the growing demand for financial assets, financial innovation and financial fragility deserves a lot more attention than it has hitherto received. Third, there is need to develop macroeconomic models that explicitly deal with the link between income distribution, asset prices and wealth distribution. One type of models that would be very well suited for these kind of analyses would be extended stock- flow consistent models (SFC), originally developed by Godley and Cripps (1983) and Godley and Zezza (1989). The currently existing SFC models (e.g. Cripps et al., 2011) make important contributions in analysing the impact of wealth on flow variables, but so far they have the shortcoming that they do not account for the existence of different investor types (e.g. HNWIs vs. ordinary households), different assets types, and the quantity dimensions of assets (Lysandrou, 2014). The incorporation of all the key channels analysed in our paper could help to overcome this shortcoming in future SFC models.

An important policy implication arising out of this analysis is that a more egalitarian distribution of income is not a luxury that can be taken care of once the crisis and regulatory issues have been resolved, but that it is necessary to reverse the actual level of absolute wealth concentration and income inequality to help contain the inherent problems of the current mode of capitalism. Given that income inequality and absolute wealth concentration have increased further since the outbreak of the crisis (OECD, 2013; Goda, 2014), decisive government intervention seems necessary to achieve this aim. 
The policy mix requires both the restoration of the link between productivity and real wage growth and progressive taxes and social policies. Hence minimum wages should increase in line with inflation and productivity and the bargaining power of workers should be strengthened through changes in the union legislation and collective bargaining coverage as well as the strengthening of the welfare state. With regard to taxes, we agree with Piketty (2014) that a wealth tax is needed. Additionally, top marginal income and estate tax rates should be raised. An indexation of these taxes would be an appropriate solution to avoid very high concentrations of income and wealth (as proposed most prominently by Shiller (2012)). One possible rule would be to link top income and wealth taxes to median incomes and wealth holdings (e.g. a highest marginal tax rate of $70 \%$ for income above 10 times the median income). Finally, tax avoidance and evasion opportunities have to be closed off. As existing governance arrangements allow the rich to be highly mobile and secretive, these policies need to be implemented on a global or at least regional scale (e.g. in the form of a minimum top marginal tax threshold in OECD countries).

\section{References}

Acharya, V.V., Drechsler, I. and Schnabl, P. (2011). 'A pyrrhic victory? Bank bailouts and sovereign credit risk'. NBER Working Paper, No.17136.

Akerlof, G.A. and Shiller, R.J. (2009). Animal Spirits: How human psychology drives the economy, and why it matters for global capitalism. Princeton: Princeton University Press.

Arestis, P. and Sawyer, M. (2011). The ongoing Euro crisis. Challenge, 54(6):6-13.

Ashcraft, A.B. and Schuermann, T. (2008). 'Understanding the securitization of subprime mortgage credit'. Federal Reserve Bank Staff Report, No.318.

Atkinson, A.B. and Brandolini, A. (2010). On Analyzing the World Distribution of Income. The World Bank Economic Review, 24(1):1-37.

Atkinson, A.B., Piketty, T. and Saez, E. (2011). Top incomes in the long run of history. Journal of Economic Literature, 49(1):3-71.

Barba, A. and Pivetti, M. (2009). Rising household debt: its causes and macroeconomic implications-a long-period analysis. Cambridge Journal of Economics, 33(1):113-37

Bassens, D., van Meeteren, M., Derudder, B. and Witlox, F. (2013). No more cred it to Europe? Cross-border bank lending, financial integration, and the rebirth of the national scale as a credit scorecard. Environment and Planning A, 45(10): 2399-419.

Behringer, J. and van Treeck, T. (2013). 'Income distribution, aggregate demand and current 
account: A sectoral perspective'. IMK Working Paper, No.125.

Behringer, J., Theobald, T. and van Treeck, T. (2014). 'Income and Wealth Distribution in Germany: A Macro-Economic Perspective'. IMK Report, No. 99e-2014.

Bernanke, B.S. (2005). "The Global Saving Glut and the U.S. Current Account Deficit". Speech delivered at the Sandridge Lecture, Virginia Association of Economists, Richmond, March 10.

Bernanke, B.S. (2011). International capital flows and the return to safe assets in the United States. Banque de France Financial Stability Review, 15:13-26.

Bertaut, C., Pounder DeMarco, L., Kamin, S.B. and Tryon, R.W. (2011). ABS inflows to the United States and the global financial crisis. Journal of International Economics, 88(2):21934.

Bhaduri, A. and Marglin, S. (1990). Unemployment and the real wage: the economic basis for contesting political ideologies. Cambridge Journal of Economics, 14(4):375-93.

Blanchard, O. (2009). 'The Crisis: Basic Mechanisms, and Appropriate Policies'. IMF Working Paper, No.WP09/80.

Blundell-Wignall, A. (2007). Structured products: implications for financial markets. Financial Market Trends, 93(2):27-57.

Borio, C, and Disyatat, P. 2011. "Global imbalances and the financial crisis: Link or no link?" BIS Working Paper, No.346.

Brenner, R. (2009). 'What is good for Goldman Sachs is good for America. The origins of the current crisis'. www.sscnet.ucla.edu/issr/cstch/papers/BrennerCrisisTodayOctober2009.pdf.

Brunnermeier, M. (2009). Deciphering the liquidity and credit crunch 2007-2008. Journal of Economic Perspectives, 23(1):77-100.

Caballero, R.J. and Krishnamurthy, A. (2009). Global Imbalances and Financial Fragility. American Economic Review, 99(2):584-88.

Caballero, R.J., Farhi, E. and Gourinchas, P.-O. (2008). Financial crash, commodity prices and global imbalances. Brookings Papers on Economic Activity, 39(2):1-55.

Costa, J. and Ricciuti (2013). 'Sources for the Euro Crisis: Bad Regulation and Weak Institutions in Peripheral Europe'. University of Verona Department of Economics Working Paper, No.15.

Coval, J., Jurek, J. and Stafford, E. (2009). The Economics of Structured Finance. Journal of Economic Perspectives, 23(1):3-25.

Crotty, J.R. (2012). The great austerity war: what caused the US deficit crisis and who should pay to fix it? Cambridge Journal of Economics, 36(1):79-104.

Cynamon B. and Fazzari, S. (2013). 'Inequality and household finance during the consumer age'. Levy Economics Institute Working Paper, No.752.

Cynamon, Barry and Steven Fazzari (forthcoming). Rising Inequality, Demand, and Growth in the U.S. Economy. European Journal of Economics and Economic Policies, 12(3).

Davies, H. (2010). Global Financial Regulation after the Cred it Crisis. Global Policy, 1(2), pp. 185-190. 
Dumenil, G. and Levy, D. (2011). The Crisis of Neoliberalism. Cambridge (MA):Harvard University Press.

Engelen, E., Erturk, I., Froud, J., Leaver, A. and Williams, K. (2010). Reconceptualizing financial innovation: frame, conjuncture and bricolage. Economy and Society, 39(1):33-63.

Foster J.B. and Magdoff F. (2009). The Great Financial Crisis: Causes and Consequences. New York:Monthly Review Press.

Froud, J., Johal, S., Haslam, C. and Williams, K. (2001). Accumulation under conditions of inequality. Review of International Political Economy, 8(1):66-95.

Fujita, K. (2011). Financial crises, Japan's state regime shift, and Tokyo's urban policy. Environment and Planning A, 43(2):307-27.

Galbraith, J.K. (1975). The great crash 1929. Boston:Houghton Mifflin.

Galbraith, J.K. (2012). Inequality and Instability. A Study of the World Economy Just Before the Great Crisis. Oxford: Oxford University Press.

Goda, T. (2014). 'Global trends in relative and absolute wealth concentration'. CIEF Working Paper, No.14-01.

Goda, T. and Lysandrou, P. (2014). The contribution of wealth concentration to the subprime crisis: a quantitative estimation. Cambridge Journal of Economics, 38(2):301-27.

Goda, T., Lysandrou, P. and Stewart, C. (2013). The Contribution of US Bond Demand to the US Bond Yield Conundrum of 2004 to 2007: An Empirical Investigation. Journal of International Financial Markets, Institutions \& Money, 27:113-36.

Godley, W. and Cripps, F. (1983). Macroeconomics. Oxford:Oxford University Press.

Godley, W. and Zezza, G (1986). “A Simple Real Stock Flow Monetary Model of the Italian Economy". University of Cambridge Working Paper.

Golub, S., Kaya, A. and Reay, M. (2014). What were they thinking? The Federal Reserve in the run-up to the 2008 financial crisis. Review of International Political Economy, DOI:10.1080/09692290.2014.932829.

Hager, S.B. (2014). What Happened to the Bondholding Class? Public Debt, Power and the Top One Per Cent. New Political Economy, 19(2):155-82.

Hein, E. (2012). The macroeconomics of finance-dominated capitalism - and its crisis. Cheltenham:Edward Elgar.

Hein, E. and Mundt, M. (2012). 'Financialisation and the Requirements and Potentials for Wageled Recovery - a Review Focussing on the G20'. ILO Conditions of Work and Employment Series, No.37.

Hein, E. and Vogel, L. (2008). Distribution and growth reconsidered -empirical results for six OECD countries. Cambridge Journal of Economics, 32(3):479-511.

Hoque, H. (2013). From the credit crisis to the sovereign debt crisis: Determinants of share price performance of global banks. International Review of Financial Analysis, 30:334-50.

IMF (2008). Global Financial Stability Report: Financial Stress and Deleveraging. Washington D.C.:IMF.

Kregel, J. (2008). Using Minsky's Cushions of Safety to Analyze the Crisis in the U.S. Subprime 
Mortgage Market. International Journal of Political Economy, 37(1):3-23.

Kumhof, M. and Ranciere, R. (2010). 'Inequality, Leverage and Crises'. IMF Working Paper, No.268.

Kumhof, M., Lebarz, C., Ranciere, R., Richter, A.W. and Throckmorton, N.A. (2012). 'Income Inequality and Current Account Imbalances'. IMF Working Paper, No.12/08.

Kumhof, M., Ranciére, R. and Winant, P. (2015). Inequality, Leverage, and Crises. American Economic Review, 105(3):1217-1245.

Langley, P. (2008). Financialization and the consumer credit boom. Competition \& Change, 12(2):133-47.

Lapavitsas, C., Kaltenbrunner, A., Lindo, D., Michell, J., Painceira, J.P., Pires, E., Powell, J., Stenfors, A. and Teles, N. (2010). Eurozone crisis: Beggar Thyself and Thy Neighbour. Journal of Balkan and Near Eastern Studies, 12(4):321-73.

Lavoie, M, 2009. Introduction to Post Keynesian economics. New York:Palgrave Macmillan

Lim, M.-H. and Khor, H.E. (2011). From Marx to Morgan Stanley: Inequality and Financial Crisis. Development and Change, 42(1):209-27.

Lysandrou, P. (2011-12). The Primacy of Hedge Funds in the Subprime Crisis. Journal of Post Keynesian Economics, 34(2):225-54.

Lysandrou, P. (2011a). Global inequality as one of the root causes of the financial crisis: a suggested explanation. Economy and Society, 40(3):323-44.

Lysandrou, P. (2011b). Global inequality, wealth concentration and the subprime crisis: A Marxian commodity theory analysis. Development and Change, 42(1):183-208.

Lysandrou, P. (2014). Post-Keynesian stock-flow models after the subprime crisis: the need for micro-foundations. Intervention, European Journal of Economics and Economic Policies, 11(1):113-126.

Major, A. (2012). Neoliberalism and the new international financial architecture. Review of International Political Economy, 19(4):536-61.

Milanovic, B. (2011). The haves and the haves not: A brief idiosyncratic history of global inequality. New York:Basic Books.

Munoz Martinez, H. and Marois, T. (2014). Capital fixity and mobility in response to the 200809 crisis: variegated neoliberalism in Mexico and Turkey. Environment and Planning D: Society and Space, 32(6): 1102-19.

Naastepad, C.W.M. and Storm, S. (2006-07). OECD demand regimes (1960-2000). Journal of Post Keynesian Economics, 29(2):211-246.

OECD (2012). 'Labour Losing to Capital: What explains the declining Labour Share?'. In Employment Outlook, Paris:OECD, Ch.3.

OECD (2013). 'Crisis squeezes income and puts pressure on inequality and poverty'. www.oecd.org/socia//soc/OECD2013-Inequality-and-Poverty-8p.pdf.

Onaran, Ö. and Galanis, G. (2014). Income distribution and aggregate demand: National and global effects" Environment and Planning A, 46(10):2489-513.

Palley, T.I. (2012). From Financial Crisis to Stagnation: The Destruction of Shared Prosperity 
and the Role of Economics, Cambridge (MA):Cambridge University Press.

Palley, T.I. (2015). 'Inequality, the Financial Crisis, and Stagnation: Competing Stories and Why They Matter'. IMK Working Paper, No.151.

Palma, J.G. (2009). The revenge of the market on the rentiers. Why neo-liberal reports of the end of history turned out to be premature. Cambridge Journal of Economics, 33(4):829-69.

Palma, J.G. (2011). Homogeneous Middles vs. Heterogeneous Tails, and the End of the "Inverted-U": It's All About the Share of the Rich. Development and Change, 42(1):87-153.

Piketty, T. (2014). Capital in the Twenty-First Century. Cambridge (MA):Belknap Press.

Rajan, R.G. (2010). Fault Lines. How Hidden Fractures Still Threaten the World Economy. Princeton:Princeton University Press.

Roubini, N. and Mihm, S. (2010). Crisis Economics: A Crash Course in the Future, New York:Penguin.

Saez, E. and Zucman, G. (2014). 'Wealth Inequality in the United States since 1913: Evidence from capitalized income tax data'. NBER Working Paper, No.20625.

Sawyer, M. (2013). Alternative economic policies for the Economic and Monetary Union. Contributions to Political Economy, 32(1):11-27.

Schuknecht, L., Moutot, P., Rother, P. and Stark, J. (2011). 'The Stability and Growth Pact Crisis and Reform'. ECB Occasional Paper Series, No.129.

Shiller, R. (2012). 'Don't Resent the Rich, Fix the Tax Code'. www.bloombergview.com/articles/2012-03-07/don-t-resent-the-rich-fix-the-tax-code-part-3robert-shiller.

Shin, H.S. (2012). Global Banking Glut and Loan Risk Premium. IMF Economic Review, 60(2):155-92.

Sidaway, J.D. (2008). Subprime crisis: American crisis or human crisis?. Environment and Planning D: Society and Space, 26(2): 195-98.

Stiglitz, J.E. (2009). The global crisis, social protection and jobs. International Labour Review, 148(1-2):1-13.

Stiglitz, J.E. (2011). Rethinking macroeconomics: What failed, and how to repair it. Journal of the European Economic Association, 9(4), pp. 591-645.

Stiglitz, J.E. (2012). The price of inequality. London:Penguin Books.

Stockhammer, E. (2016a). Neoliberal growth models, monetary union and the Euro Crisis. A post-Keynesian perspective. New Political Economy, forthcoming

Stockhammer, E. (2016b). Why have wage shares fallen? A panel analysis of the determinants of functional income distribution. British Journal of Industrial Relations, forthcoming.

Stockhammer, E. (2015). Rising Inequality as a cause of the present crisis. Cambridge Journal of Economics, 39(3): 935-958.

Stockhammer, E. and Onaran, Ö. (2012). Rethinking wage policy in the face of the Euro crisis. Implications of the wage-led demand regime. International Review of Applied Economics, 26(2):191-203. 
Stockhammer, E., Onaran, Ö. and Ederer, S. (2009). Functional income distribution and aggregate demand in the Eurozone. Cambridge Journal of Economics, 33(1):139-59.

Storm, S. and Naastepad, C.W.M. (2015a). Europe's Hunger Games: income distribution, cost competitiveness and crisis. Cambridge Journal of Economics, 39(3):959-986.

Storm, S. and Naastepad, C.W.M. (2015b). Crisis and recovery in the German economy: The real lessons. Structural Change and Economic Dynamics, 32:11-24.

Storm, S. and Naastepad, C.W.M. (2015c). NAIRU economics and the Eurozone crisis. International Review of Applied Economics, 29(6):843-877.

Taylor, J.B. (2009). Economic Policy and the financial crisis: An empirical analysis of what went wrong. Critical Review, 21(2-3):341-64.

van Treeck, T. (2014). Did inequality cause the U.S. financial crisis?. Journal of Economic Surveys, 28(3):421-48.

Vidal, M. (2013). Postfordism as a dysfunctional accumulation regime: a comparative analysis of the USA, the UK and Germany. Work Employment Society, 27(3):451-71

Wisman, J.D. (2013). Wage stagnation, rising inequality and the financial crisis of 2008. Cambridge Journal of Economics, 37(4):921-45.

Wisman, J.D. and Baker, B. (2012). 'Rising inequality and the financial crisis of 1929 and 2008'. American University Department of Economics Working Paper, No.2011-01.

Wolff, E.N. (2010). Recent trends in household wealth in the United States: Rising debt and the middle-class squeeze-An Update to 2007. Levy Economics Institute Working Paper, No.589.

Wolff, E.N. (2012). 'The asset price meltdown and the wealth of the middle class'. NBER Working Paper, No.18559. 